\title{
Keberhasilan Persilangan Tomat Varietas Komersial (Lycopersicum esculentum L.) dengan Tomat Mutan Tahan Simpan
}

\author{
The Success of Crossing Between Commercial Tomato \\ Variety (Lycopersicum esculentum L.) with the Shelf Life \\ Mutant Tomato Sletr1-1 and Sletr 1-2
}

\author{
Gungun Wiguna, ${ }^{1,2}$, Elfira Rosalita ${ }^{3}$, Anas ${ }^{4}$, Neni Rostini ${ }^{4}$, Syariful \\ Mubarok $^{4}$, dan Hirosi Ezura ${ }^{5}$ \\ ${ }^{1}$ Program Pascasarjana, Fakultas Pertanian, Universitas Padjadjaran \\ ${ }^{2}$ Balai Penelitian Tanaman Sayuran, Badan Litbang Pertanian \\ ${ }^{s}$ Program Sarjana, Fakultas Pertanian, Universitas Padjadjaran \\ ${ }^{7}$ Departemen Budidaya Pertanian, Fakultas Pertanian, Universitas Padjadjaran \\ ${ }^{5}$ Tsukuba Plant Innovation Research Center, University of Tsukuba, Tsukuba 305- \\ 8572, Japan
}

\begin{abstract}
Post-harvest loss is an obstacle for tomato farmers that cause tomato farming being unprofitable. Utilization of mutant genes prolong tomato fruit shelf life through crossing is one of the best solutions to improve the fruit quality. The objective of this study was to determine the success of cross-pollination between commercial tomato varieties and shelf life of mutant tomatoes. Two mutant tomato lines Sletr 1-1 and Sletr 1-2, and one wild type strain were crossed with four commercial varieties (Intan, Mutiara, Ratna, and Mirah ). The results showed that the success rate of crossing ranged from $77.50 \%$ to $100 \%$, with an average of $95.76 \%$. The average maximum growth potential of seeds produced was $89.17 \%$ with the lowest value of $75 \%$ and the highest $98.5 \%$. The most top success of crosses was built by a combination of crossing Ratna x Sletr 1-2, and the combination of Mirah x Sletr 1-1 showed the lowest percentage of the crossing. The Intan showed the highest success as female parent of crossing, while Mirah was the lowest production of the crossing. The plant height of all hybrid was smaller compared to the commercial varieties.
\end{abstract}

Keywords: Crossing, Lycopersicum esculentum, Sletr 1-1, Sletr 1-2, tomatoes

\begin{abstract}
Abstrak: Kehilangan hasil pada pasca panen merupakan kendala yang mengakibatkan usahatani tomat menjadi tidak menguntungkan. Pemanfaatan gen mutan pengendali ketahanan simpan buah tomat melalui persilangan merupakan salah satu solusi yang terbaik yang dapat dilakukan. Penelitian bertujuan untuk mengetahui tingkat keberhasilan pesilangan dalam upaya mengintogresikan gen pengendali ketahanan simpan pasca panen buah tomat kedalam varietas komersial yang telah beradaptasi baik di Indonesia. Dua galur mutan tomat Sletr 1-1 dan Sletr 1-2, dan satu galur tetua asal (wild type), disilangkan dengan empat varietas komersial (Intan, Mutiara, Ratna dan Mirah). Hasil penelitian menunjukkan bahwa tingkat keberhasilan persilangan berkisar antara $77.50 \%$ hingga $100 \%$ dengan rerata $95,76 \%$. Rerata potensi tumbuh maksimun dari benih yang dihasilkan $89.17 \%$ dengan nilai terendah $75 \%$ dan tertinggi $98.5 \%$. Keberhasilan persilangan tertinggi dihasilkan oleh kombinasi persilangan Ratna x Sletr1-2 dan terendah dihasilkan oleh kombinasi persilangan Mirah x Sletr1-1. Tetua betina dengan keberhasilan persilangan tertinggi dihasilkan oleh Intan dan terendah Mirah. Terjadi perubahan tinggi pada tanaman F1 hasil persilangan dibandingkan tetua komersialnya.
\end{abstract}

Kata kunci: Persilangan, Lycopersicum esculentum, Sletr 1-1, Sletr 1-2, tomat

\section{Pendahuluan}

Tomat merupakan tanaman hortikultura yang banyak dibudidayakan petani bukan hanya di Indonesia tetapi juga di banyak negara di dunia.
Keragaman manfaat yang dimiliki buah tomat menjadi daya tarik banyak petani untuk membudidayakannya. Pemintaan akan buah tomat di Indonesia cukup tinggi. Berdasarkan data Survei Sosial Ekonomi Nasional (SUSENAS), menunjukkan 
bahwa selama tahun 2002 - 2016 terjadi peningkatan konsumsi buah tomat sebesar 19,42\% per tahun (BPS, 2017).

Berdasarkan pada proses fisiologis pematangan buah, tomat termasuk ke dalam buah klimaterik, sehingga rentan terhadap kerusakan. Karakter buah klimaterik ditandai dengan tetap berlangsungnya aktivitas respirasi, transpirasi, dan metabolisme pada buah tomat walapun buah tersebut telah dipanen ataupun disimpan (Normasari, 2002). Di beberapa negara berkembang tingkat kehilangan hasil panen sebagai akibat buah tomat yang mudah rusak bisa mencapai lebih dari 42\% (Arah et al., 2015). Hal ini bukan hanya mengakibatkan usaha tani tomat menjadi tidak efisien tetapi juga mengakibatkan kerugian bagi para pelaku usaha buah tomat.

Etilen merupakan salah satu hormon pertumbuhan yang memiliki peran utama dalam pematangan buah klimaterik. Menurut Nazar, et al. (2014) etilen yang dihasilkan oleh tanaman memiliki peran ganda dalam mengontrol pertumbuhan sekaligus penuaan pada tanaman. Melalui pengendalian produksi maupun sensitivitas tanaman terhadap etilen diduga dapat menekan proses pematangan buah.

Pada tanaman tomat teridentifikasi enam gen reseptor etilen, yaitu SlETR1, SlETR2, SlETR3/NR, SlETR4, SlETR5, dan SlETR6 yang menjadi koleksi Micro-tom library Japan, University of Tsukuba dan telah dilakukan mutasi pada gen reseptor SlETR1 sehingga diperoleh Sletr 1-1 dan Sletr 1-2. Kedua gen tersebut diketahui efektif dalam menekan sensitivitas terhadap etilen sehingga dapat meningkatkan daya simpan buah (Mubarok et al., 2015).

Perakitan varietas kearah ketahanan umur simpan pada buah, merupakan solusi terbaik yang dapat dilakukan untuk mengurangi kerusakan pascapanen tomat. Perakitan dapat dilakukan melalui persilangan antar tetua yang memiliki karakter tahan simpan dengan tetua lainnya yang memiliki karakter hasil dan agronomi baik. Persilangan varietas tomat komersial koleksi Balai Penelitian Tanaman Sayuran (BALITSA), yang memiliki karakter agronomi dan hasil baik, serta mampu beradaptasi di lingkungan tumbuh Indonesia seperti varietas Intan, Mirah, Ratna, dan Mutiara dengan mutan Sletr1-1 dan Sletr1-2 dapat memfasilitasi pengembangan tanaman tomat dengan ketahanan simpan panjang.

Keberhasilan suatu persilangan pada suatu tanaman dipengaruhi oleh beberapa faktor, diantaranya pertumbuhan tanaman tetua, sinkronisasi waktu berbunga Multhoni et al. (2012), kerontokan bunga sebelum atau setelah fertilisasi, rendahnya produksi polen, polen tidak viabel, mandul jantan, dan self incompatibility (Handayani, 2014). Penelitian ini bertujuan untuk mengetahui tingkat keberhasilan persilangan antara galur mutan Sletr 1-1 dan Sletr 1-2 dengan varietas Intan, Mirah, Ratna, dan Mutiara yang telah beredar dan beradaptasi baik di Indonesia.

\section{Bahan dan Metode}

\section{Materi Genetik}

Bahan tanaman yang digunakan dalam penelitian ini adalah 5 tanaman tetua betina masing-masing dari empat varietas unggul tropis yaitu Intan, Mutiara, Ratna serta dan Mirah, lima tanaman tetua jantan dari tomat tipe liar (WT) serta dua mutannya Sletr 1-1 dan Sletr1-2. Bahan lain yang digunakan meliputi media persemaian berupa campuran tanah dan pupuk kandang dengan perbandingan 1:1, media tanam berupa tanah, pupuk kandang dan dolomit serta pupuk kimia, pupuk organik cair dan pestisida.

\section{Persilangan Tomat Komersial dan Mutan}

Penelitian persilangan dilaksanakan pada bulan Maret - Agustus 2017 di kebun percobaan Balai Penelitian Sayuran Lembang pada ketinggian $1250 \mathrm{~m}$ dpl dengan jenis tanah andosol, suhu minimum ratarata $10{ }^{\circ} \mathrm{C}$, suhu maksimum rata-rata $27{ }^{\circ} \mathrm{C}$, kelembaban udara minimum rata-rata $80 \%$ dan kelembaban udara maksimum rata-rata $92 \%$. Persilangan dilakukan dengan skema line $\mathrm{x}$ tester. Setiap satu kombinasi persilangan menggunakan 40 bunga tanaman betina. Kegiatan persilangan dilakukan di rumah kassa dengan luasan 100m2.

Panen bunga untuk diambil serbuk sarinya dilakukan pagi hari (07.00-09.00) saat bunga mencapai antesis, yaitu mahkota bunga telah membuka sempurna, tetapi anteranya belum pecah. Bunga yang telah dipanen disimpan diruang ber AC pada suhu $18{ }^{\circ} \mathrm{C}$ selama 24 jam. Ekstraksi serbuk sari dilakukan dengan cara menggetarkan kotak sari dengan stik penggetar dan serbuk sari yang jatuh ditampung di petridish. Serbuk sari yang dihasilkan di masukkan kedalam cincin yang khusus dirancang untuk memudahkan polinasi.

Persilangan dilakukan pada pagi hari mulai pukul 9.00 wib hingga 12 wib. Setiap 1 kombinasi persilangan membutuhkan 40 bunga betina untuk diserbuki. Pengamatan keberhasilan dilakukan setelah persilangan terakhir berumur satu minggu. Pengamatan dilakukan terhadap semua bunga yang berhasil menjadi buah, buah yang gugur dan bunga yang tidak berkembang. Pemeliharaan tanaman betina dilakukan sesuai dengan budidaya petani. Buah dipanen pada saat masak fisiologis yang dicirikan oleh warna buah mencapai warna merah $\geq 90 \%$.

Pengamatan keberhasilan persilangaan dilakukan terhadap prosentase buah hasil persilangan yang 
terbentuk, jumlah benih dan viabilitas benih yang dihasilkan. Prosentase buah hasil persilangan yang terbentu dihitung dengan rumus:

Persentase pembentukan buah $=$

$$
\frac{\sum \text { buah yang dipanen }}{\Sigma \text { bunga yang diserbuki }} \times 100 \%
$$

Viabilitas benih yang diukur berdasarkan Prosentase Tumbuh Maksimum (PTM) yang dihitung berdasarkan rumus:

$$
\text { PTM }=\frac{\Sigma \text { Kecambah tumbuh }}{\Sigma \text { benih disemai }} \times 100 \%
$$

\section{Penampilan Hibrida}

Penampilan hibrida dilaksanakan mulai bulan Oktober 2017 hingga Januari 2018 di Balai Penelitian Sayuran (BALITSA), Lembang, Kabupaten Bandung Barat, Jawa Barat. Ketinggian tempat yaitu 1250m di atas permukaan laut (dpl). Rancangan percobaan yang dilakukan adalah Rancangan Acak Kelompok (RAK) satu faktor, yaitu genotipe dengan 4 ulangan. Analisis data percobaan menggunakan Student's T-Test, untuk melihat keberhasilan persilangan dari perubahan tinggi tanaman hibridanya. Pengamatan dilakukan dengan membandingkan fenotipik hibrida hasil persilangan dengan tetua komersialnya. Tinggi tanaman diukur mulai dari pangkal batang pada ruas pertama sampai titik tumbuh tertinggi. Pengukuran tinggi tanaman dilakukan pada umur tanaman 8 MST.

\section{Hasil Dan Pembahasan}

Salah satu kriteria yang menunjukkan keberhasilan dari sebuah persilangan adalah berkembangnya bunga yang dipolinasi menjadi buah. Berdasarkan prosentase persilangan yang berhasil (Tabel 1.), hasil tertinggi diperoleh dari persilangan antara Ratna dengan Sletr 1-2 (100\%) dan terendah dihasilkan dari persilangan antara Mirah dengan Sletr 1-1 (77.50\%). Berdasarkan latar belakang tetua betina yang digunakan dalam persilangan, varietas Intan menunjukkan keberhasilan persilangan terbaik (90.83\%) dibandingkan dengan varietas komersial lainnya. Prosentase keberhasilan persilangan terendah dihasilkan oleh Mirah sebagai tetua betina $(85.00 \%)$.

Tidak semua persilangan yang berhasil menjadi buah dapat mencapai masak fisiologis, sebagian diantaranya gugur. Prosentase buah gugur tertinggi (38.64\%) dihasilkan dari persilangan yang melibatkan Ratna dan terendah (9.17\%) dihasilkan dari persilangan yang melibatkan Intan sebagai tetua betina.

Keberhasilan polinasi dipengaruhi oleh faktor genetik yaitu banyaknya jumlah serbuk sari yang menempel pada permukaan stigma (Marcucci dan
Visser, 1987; Sutapradja, 2008). Faktor lingkungan seperti iklim, tanah, teknik bercocok tanam (Hammer et. al., 1995; Sutapradja, 2008), tingkat serangan hama dan penyakit juga menjadi pembatas keberhasilan persilangan. Selain itu, pemilihan bunga yang kurang tepat, cara emaskulasi yang salah dan saat menyentuhkan polen ke putik yang kurang hati-hati, juga dapat mengakibatkan polinasi tidak berhasil.

Sebagian buah pada polinasi yang berhasil, gugur sebelum memasuki umur masak fisiologis. Gugurnya buah diakibatkan karena beberapa faktor, diantaranya faktor mekanis dan penyakit. Faktor mekanis berupa kontak fisik pada buah hasil polinasi, yang terjadi saat melakukan polinasi pada bunga yang berada satu tandan dengan buah tersebut. Penyakit yang menjadi penyebab gugurnya buah adalah busuk pada pangkal buah.

Jumlah benih yang dihasilkan dari persilangan disajikan pada tabel 2. Jumlah benih terbanyak (127.96) dihasilkan oleh persilangan yang melibatkan mutiara dan paling sedikit $(79,67)$ dihasilkan oleh persilangan yang melibatkan Intan sebagai tetua betina. Perbedaan dalam kemampuan menghasilkan benih disebabkan karena faktor genetik maupun lingkungan. Menurut Sutapradja (2008) terganggunya perkembangan daun pada fase generatif dapat menjadi salah satu penyebabnya. Pada fase ini hasil fotosintesis dari daun digunakan untuk pertumbuhan dan perkembangan bunga menjadi buah hingga akhirnya dapat di panen. Terganggunya perkembangan daun umumnya disebabkan oleh faktor lingkungan seperti ketersediaan air, cahaya dan serangan hama penyakit. Kisaran jumlah benih per buah antara 67.50 - 184.13 butir, dengan rerata 113.23 butir benih per buah.

Benih yang bermutu dapat menghasilkan tanaman bermutu atau dapat menghasilkan tanaman yang berproduksi normal. Mutu benih mencangkup 3 hal yang tidak terpisahkan, yaitu mutu genetik yang mengemukakan tingkat kemurnian benih, mutu fisiologi dengan tingkat viabilitas benih dan mutu fisik dengan tingkat kebersihan benih (Sadjad, 1993). Salah satu parameter dalam menentukan viabilitas benih adalah PTM. Berdasarkan Tabel 3 semua kombinasi persilangan menghasilkan benih dengan nilai prosentase PTM diatas $70 \%$. PTM terendah dihasilkan dari benih hasil persilangan antara Mirah dengan Sletr 1-2 dan PTM tertinggi dari benih hasil persilangan antara Intan dengan Sletr 1-2.

Tinggi tanaman merupakan salah satu parameter pertumbuhan yang dapat diamati guna mengetahui hibrida tanaman hasil persilangan. Analisis tinggi tanaman melalui uji Student's T-Test pada 12 genotipe $\mathrm{F} 1$ dibandingkan dengan tetua komersialnya masing-masing menunjukkan hasil tidak signifikan 
Tabel 1 Rerata prosentase keberhasilan persilangan menjadi buah

\begin{tabular}{|c|c|c|c|c|c|c|c|}
\hline No & $\begin{array}{l}\text { Kombinasi } \\
\text { pesilangan }\end{array}$ & $\begin{array}{c}\text { Persilangan } \\
\text { berhasil }\end{array}$ & $\begin{array}{l}\text { Persilangan } \\
\text { berhasil } \\
\text { berdasarkan } \\
\text { tetua betina }\end{array}$ & $\begin{array}{c}\text { Persilangan } \\
\text { gagal }\end{array}$ & $\begin{array}{l}\text { Persilangan } \\
\text { gagal } \\
\text { berdasarkan } \\
\text { tetua betina }\end{array}$ & $\begin{array}{l}\text { Buah } \\
\text { gugur }\end{array}$ & $\begin{array}{l}\text { Buah gugur } \\
\text { berdasarkan } \\
\text { tetua betina }\end{array}$ \\
\hline 1 & Intan x WT & 90.00 & & 10.00 & & 16.13 & \\
\hline 2 & Intan x Sletr 1-1 & 90.00 & 90.83 & 10.00 & 9.17 & 5.88 & 11.38 \\
\hline 3 & Intan x Sletr 1-2 & 92.50 & & 7.50 & & 12.12 & \\
\hline 4 & Mutiara x WT & 92.50 & & 7.50 & & 12.12 & \\
\hline 5 & Mutiara x Sletr 1-1 & 80.00 & 88.33 & 20.00 & 11.67 & 10.34 & 23.49 \\
\hline 6 & Mutiara x Sletr 1-2 & 92.50 & & 7.50 & & 48.00 & \\
\hline 7 & Ratna $\mathrm{x}$ WT & 80.00 & & 20.00 & & 23.08 & \\
\hline 8 & Ratna x Sletr 1-1 & 90.00 & 90.00 & 10.00 & 10.00 & 50.00 & 38.64 \\
\hline 9 & Ratna x Sletr 1-2 & 100.00 & & 0.00 & & 42.86 & \\
\hline 10 & Mirah x WT & 90.00 & & 10.00 & & 28.57 & \\
\hline 11 & Mirah x Sletr 1-1 & 77.50 & 85.00 & 22.50 & 15.00 & 0.00 & 17.86 \\
\hline 12 & Mirah x Sletr 1-2 & 87.50 & & 12.50 & & 25.00 & \\
\hline
\end{tabular}

Tabel 2 Rerata produksi benih hasil persilangan dan viabilitasnya

\begin{tabular}{|c|c|c|c|c|c|}
\hline No & Persilangan & $\begin{array}{c}\text { Jumlah Benih } \\
\text { Per Buah }\end{array}$ & $\begin{array}{c}\text { Jumlah Benih } \\
\text { berdasarkan tetua } \\
\text { betina }\end{array}$ & $\begin{array}{c}\text { Berat } \\
\text { 1000 Benih } \\
(\mathrm{g})\end{array}$ & $\%$ PTM \\
\hline 1 & Intan x WT & 105.63 & & 3.03 & 93.00 \\
\hline 2 & Intan x Sletr 1-1 & 141.13 & 124.08 & 2.78 & 78.50 \\
\hline 3 & Intan x Sletr 1-2 & 125.50 & & 3.05 & 96.00 \\
\hline 4 & Mutiara x WT & 98.75 & & 3.32 & 98.50 \\
\hline 5 & Mutiara x Sletr 1-1 & 67.50 & 79.67 & 3.28 & 91.00 \\
\hline 6 & Mutiara x Sletr 1-2 & 72.75 & & 3.53 & 90.50 \\
\hline 7 & Ratna x WT & 131.50 & & 3.35 & 93.00 \\
\hline 8 & Ratna x Sletr 1-1 & 98.88 & 127.96 & 3.43 & 83.00 \\
\hline 9 & Ratna x Sletr 1-2 & 153.50 & & 3.56 & 93.00 \\
\hline 10 & Mirah x WT & 184.13 & & 2.94 & 91.00 \\
\hline 11 & Mirah x Sletr 1-1 & 84.13 & 121.21 & 2.87 & 87.50 \\
\hline 12 & Mirah x Sletr 1-2 & 95.38 & & 2.91 & 75.00 \\
\hline
\end{tabular}

pada Intan x WT, Mutiara x WT, dan Mutiara x Sletr1-2, sedangkan 9 genotipe F1 lainnya menunjukkan hasil analisis tinggi tanaman signifikan lebih rendah. Hasil ini menunjukkan adanya perubahan karakter pada F1 dibandingkan dengan tetua komersialnya. Perubahan ini disebabkan karena adanya rekombinasi gen dari kedua tetuanya. Patut diduga bahwa gen Sletr 1-1 dan Sletr 1-2 yang dimiliki oleh tetua mutant turut mempengaruhi terjadinya perubahan tinggi pada tanaman $\mathrm{F} 1$ hasil persilangan.

Etilen memiliki peran dalam menghambat pertumbuhan tanaman, salah satunya perpanjangan batang. Etilen mengakibatkan respon rangkap tiga (triple responses) pada pertumbuhan tanaman yang terdiri atas penghambatan pemanjangan batang, peningkatan pertumbuhan lateral (penebalan batang), dan pertumbuhan horizontal yang abnormal (Taiz and Zeiger, 2002). Rendahnya rata-rata tinggi tanaman pada seluruh hasil persilangan dibandingkan dengan tetua komersialnya masing-masing diduga karena adanya interaksi gen-gen antar kedua tetua, serta adanya interaksi antara genotipe dan lingkungan. 


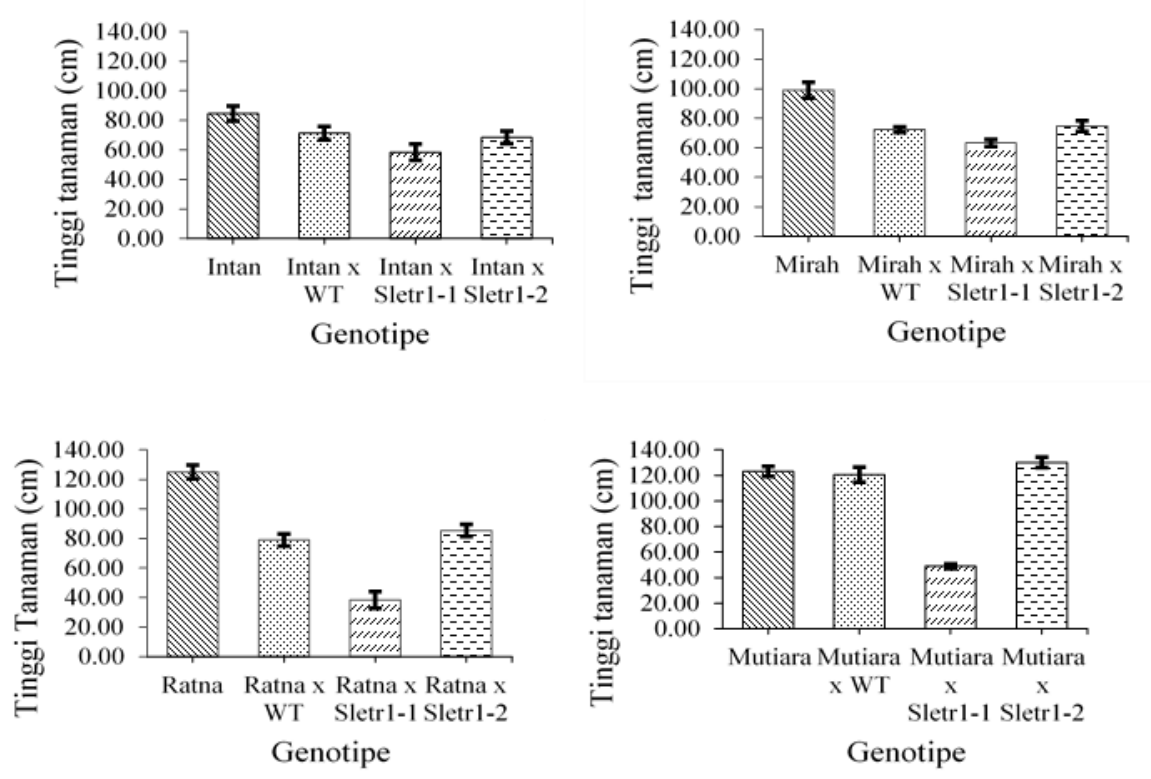

Gambar 1 Tinggi tanaman 16 kombinasi persilangan tomat pada 8 MST. Nilai rata-rata \pm Standar Error $(\mathrm{SE})\left(\mathrm{n}_{\text {sampel }}=20\right)$ yang diikuti dengan lambang bintang satu menunjukkan adanya perbedaan yang signifikan dibandingkan dengan Tetua Komersial menurut uji Student's T-Test pada taraf $\mathrm{p}<0,05$.

\section{Kesimpulan dan Saran}

Persilangan antara tomat varietas komersial dan mutan berhasil dilakukan dengan tingkat keberhasilan antara $77.50 \%$ hingga 100\% dengan rerata $95,76 \%$. Viabilitas benih yang ditunjukkan oleh potensi tumbuh maksimun berkisar antara $75 \%$ dan tertinggi $98.5 \%$. Tetua betina dengan keberhasilan persilangan tertinggi dihasilkan oleh Intan dan terendah Mirah. Terjadi perubahan tinggi pada tanaman F1 menunjukkan adanya rekombinasi gen tetua sebagi hasil daari persilangan. Sebagai saran, perlu evaluasi pada tanaman F1 terkait karakter lainnya yang menyangkut hasil dan kualitas buah.

\section{Daftar Pustaka}

Arah, I.K., Amaglo, H., Kumah, E.K. \& Ofori, H. 2015. Preharvest and postharvest factors affecting the quality and shelf life of harvested tomatoes: A mini-review. International Journal of Agronomy, 2015: 1-6.

Badan Pusat Statistik. 2017. Statistik Tanaman Sayuran dan Buah-buahan Semusim. ISSN: 2088 - 8392. Diakses melalui www.bps.go.id
Hammer, G.L., Sinclair T.R., Boote, K.J., Wright, G.C., Mienke, H., and Bell, M.J., 1995. A Peanut Simulation Model I: Model Development and Testing, Agronomy Journal 87 (6): 1085-1093.

Handayani, T. 2014. Persilangan Untuk Merakit Varietas Unggul Baru Kentang. Iptek Tanaman Sayuran No.004.

Marcucci, M.C., and T. Visser. 1987. Pollen tube growth in apple and pear styles in relation to self-incompatibility, incongruity and pollen load. Adv. Hort. Sci. 1:90-94.

Mubarok, S., Okabe, Y., Fukuda, N., Ariizumi, T. \& Ezura, H. 2015. Potential Use of a Weak Ethylene Receptor Mutant, Sletr1-2, as Breeding Material, To Extend Fruit Shelf Life of Tomato. Journal of Agricultural and Food Chemistry, 63: 7995-8007.

Multhoni, J, Shimelis, H, Melis, R \& Kabira, J 2012, 'Reproductive biology and early generation's selection in conventional potato breeding', AJCS, vol. 6, no. 3, pp. 488-497.

Nazar, R., Khan, M. I. R., Iqbal, N., Masood, A., and Khan, N. A. (2014). Involvement of ethylene in reversal of salt-inhibited photosynthesis by sulfur in mustard. 
Physiol. Plant. 152, 331-344. doi: 10.1111/ppl.12173

Normasari, F. dan B. S. Purwoko. 2002. Pengaruh pemberian $\mathrm{CaCl} 2$ prapanen terhadap perubahan kualitas tomat segar selama penyimpanan. Bul. Agron. 30: 53-57.

Putri, H. R., Erlina A., dan Rudi H. M. 2014. Evaluasi interaksi genotipe dan lingkungan enam galur mutan harapan tomat (Solanum lycopersicum L.) di dataran rendah dan dataran tinggi. Vegetalika. 3(4):63-76.

Sutapradja, H, 2008, Pengaruh Pemangkasan Pucuk Terhadap hasil dan Kualitas Benih Lima Kultivar Mentimun, J.Hort. (18) 1: 16-20.

Sadjad, S. 1993. Dari Benih Kepada Benih. Jakarta: PT. Gramedia

Taiz, L. and Zeiger E. 2002. Plant Physiology. 3rd Edition. Sinauer Associates .Sunderland. pp.116-119. 